\title{
THE EFFECT OF EDUCATION USING VIDEO ANIMATION ON ELEMENTARY SCHOOL IN HAND WASHING SKILL
}

\author{
Fauzul Hayat ${ }^{1}$ \\ ${ }^{1}$ Universitas Faletehan \\ Email : fauzulhayat@yahoo.co.id
}

\begin{abstract}
This study aims to determine the effect of education using video animation on an elementary school in handwashing skill. The sample in this study was elementary school students class VI Cigabus Serang which consists of 60 students. This study uses a quantitative approach with a quasi experimental single group pretest posttest design. The results of the study showed that the pretest revealed knowledge $(26,7 \%)$ and excellent hand washing skills $(8,3 \%)$, and in posttest revealed knowledge (70\%) and excellent hand washing skills $(73,3 \%)$. Handwashing health education using video animation was effective to increase the knowledge and skills of school children regarding the proper of handwashing in elementary school $(\mathrm{p}=0.000)$ at a significant level $\alpha=0.05$. Education using video animation affects handwashing behavior among elementary school students.
\end{abstract}

Keywords: Video animation, Elementary school, Handwashing skill.

\section{INTRODUCTION}

There is a high incidence of hand hygiene $(\mathrm{HH})$ related diseases among children in Indonesia. Hand hygiene related illnesses such as diarrhoea and respiratory diseases, contribute to the burden of disease in Indonesia. Baseline health research 2018, the high proportion of diarrhoea among children is $12,8 \%$ and respiratory diseases is $10,6 \%$ between all populations in Indonesia. (Riskesdas,2018) Handwashing is the act of washing hands with plain or antimicrobial soap and water and it is the single most preventive measure for reducing the spread of contagious diseases. In fact skin is the body's first line of defense against bacteria, therefore careful attention to hand care is an essential part of the hand hygiene program. (Buda et al, 2018:206) Wash your hands frequently and in a manner the right one (for at least 20-30 seconds) is one of the most important steps to prevent virus infection. Handwashing with soap is much more effective at killing germs, bacteria, and viruses compared with wash your hands with water only. (Kemenkes RI, 2020:1)

Handwashing using soap behavior is part of hygiene and healthy behavior at the children as an effort to empower of the children to accept, willing, and able to do health and hygiene behaviors. Hand washing behavior in children remains a problem. Baseline health research 2018, 
the proportion of correct behavior in hand washing of the Indonesian population, especially among children is $43 \%$. (Riskesdas, 2018) The cause is associated with a lack of knowledge and practice in hand washing with soap (Marantika \& Dwihestie., 2020).

School children can be important behavior change agents in the community and schools improve their knowledge and change their behavior through participation, (Garg et al.,2013). Educational videos have become an important part of elementary education. (Brame., 2016). Video animation is designed to support and enhance clean hands lesson planning. The content uses best practice health and hygiene information, presented in a way that appeals to students in stages of school. asserted that videos have unique features to enhance or support classroom based and teacher led learning approaches. Assisted by other studies (Wiana., et al. 2018:6) students become easier to understand the material presented using animation video media.

The existence of learning videos animation is intended to make the students understand the topics presented more easily. In addition, animated videos also prevent students from getting bored, because animated videos are able to present a pleasant, humorous and relaxed atmosphere, but do not override material elements that are the main aspects (Naylor \& Keogh, 2013). The animation media, as the alternative media for the students, provides a better experience for students. (Gellerstedt et al., 2018). Especially if enriched with multimedia (picture, animation, music, sound), a video can motivate, attract and gather the students attention. (Yakovleva \& Goltsova., 2016).

Based on the researchers' experience during the field experience practice (PPL) in SD Negeri Cigabus Serang, it was found that there were many students did not correct behavior in hand washing with soap. The student did not know how many important handwashing with soap, especially the best practice of handwashing skill with soap. From that reasons above, there must be an appropriate method to develop the education handwashing skill of the students. We know there are many kinds of strategy in education handwashing skill such as lecture, presentation audiovisual, video and atc. But, in this opportunity the researchers offer education used video animation in improving students' handwashing skills that may become one of the alternative ways. Some studies showed that education used video animation enhances and stimulates students' motivation in improving the handwashing skills.

Based on the results of (Hapsari., et al, 2019:1254) shows that the experimental group that used motion graphic animation video media in science learning group 5 elementary schools in Sukoharjo City, obtained better learning achievement results compared to the control group 
that did not use animated video motion graphic media on subjects in the 5 elementary school science group. The average score of the experimental group posttest is 71.72 . The average posttest value of the control group was 65.67. The average difference between the two groups is 6.05. The increase in the value of the pretest results of the two groups before being treated until the posttest results after being given treatment, the largest increase was obtained by the experimental group. The increase in the experimental group score was 21.11 and the increase in the control group was 17.40. It indicates that the results of the increase in the score of the experimental group are greater than the increase in the control group score. Then it can be concluded that motion graphic video media is more effective than conventional learning.

Based on the description and thoughts above, the researcher is interested in conducting research with the title: " The effect of education using video animation on elementary school in hand washing skill".

\section{METHOD}

\section{A. Research Design}

Research design that used by researchers is quantitative research. Quantitative research is a research using objective measurement to gather numeric data that are used to answer questions or test predetermined hypothesis. (Rajagukguk, 2020: 98).

This research uses the quasi experimental design, which consists of one group pretestposttest design. There is no control group for comparison which is means there is only single group participant of the research. The same assessment and treatment are given because the participants are part of single condition. Implementation of pretest and posttest are the part of linear ordering to conduct the data before and after treatment. (Adityia,2020:118)

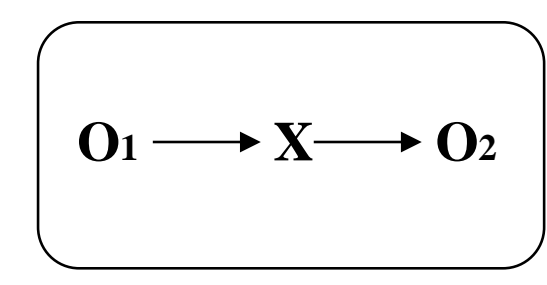

Source: Wibowo, (2014)

Information :

O1 = Pre test score

$\mathrm{X}=$ Video animation (hand washing with soap intervention) 


\section{B. Population and Sample}

\section{Population}

Population is a large number of subjects who have certain characteristics. According to Ary, Jacobs, and Sorensen (2010:167) Population is defined as all members of any well-defined class of people, events or objects. The study population was all student from the $6^{\text {th }}$ grade student of elementary schools at SD Negeri Cigabus Serang year 2019. They were consists of 60 elementary students.

\section{Sample}

Sample is part of the population selected in a certain way to represent the population. (Sastroasmoro \& Ismael., 2011:90). The $6^{\text {th }}$ grade students of SD Negeri Cigabus were a sample of the research that consisted of 60 students. The number of 60 students could be used in experimental research. In this study, the sample was taken by total sampling. As stated by (Sugiono: 2010: 74), Total sampling is a sampling technique when all members of the population used as a sample.

\section{Research instrument}

Research instrument created pretest and posttest as instrument for collecting the data. The treatment instrument focused on determining the suitable handwashing with soap based on video animation. The video animation detailed steps of handwashing composed of 6 steps (from step 0 to step 6) were used to test children's knowledge and prior skills of handwashing technique. To properly wash your hands using the superior six-step method begin by (1) wetting hands with water and grab either a dollop of soap or hand rub (2) Begin rubbing your palms together with your fingers closed, then together with fingers interlaced. (3) Move your right palm over left dorsum with interlaced fingers and vice versa, make sure to really rub in between your fingers. (4) Then interlock your fingers and rub the back of them by turning your wrist in a half circle motion. (5) Clasp your left thumb in your right palm and rub in in a rotational motion from the tip of your fingers to the end of the thumb, then switch hands. (6) And finally scrub the inside of your right hand with your left fingers closed and the other hand. (Kemenkes RI.,2019).

The pretest was conducted before the treatment. The treatment by using handwashing with soap video animation to the student. The process of conducting the posttest after the 
treatmen. After conducting the data of pretest and posttest, the analysis of the data were done to determine whether or not the effect of the handwashing with soap video animation. The last was to give a conclusion of the effect of handwashing with soap video animation to the student.

\section{Data Analysis}

The data analysis was useed of SPSSX 20 program had function to determine the descriptive analysis was included mean, median, variance, standard deviation, maximum and minimum score. The inferential analysis used t-test value, and effect size. The inferential analysis had purpose to determine whether or not the significant effect of washing hand with soap video animation.

\section{E. FINDINGS AND DISCUSSION}

\section{Findings}

Based on the results of the study, it was found the knowledge of handwashing with soap before intervention $(26,7 \%)$. After the intervention, there was an increasing knowledge of handwashing with soap in which all 42 respondents (70\%). An increase of 43,3\% in knowledge was observed after the use of video animation. (See table 1).

Table 1 Description of Children Knowledge in Hand Washing with Soap

\begin{tabular}{|c|c|c|c|c|c|}
\hline \multirow[t]{2}{*}{ Knowledge } & \multicolumn{2}{|c|}{ Before Intervention } & \multicolumn{2}{|c|}{ After Intervention } & \multirow{2}{*}{$\begin{array}{c}\text { Enhancement } \\
(\%)\end{array}$} \\
\hline & $\mathrm{N}$ & $(\%)$ & $\mathrm{n}$ & $(\%)$ & \\
\hline $\mathrm{Bad}$ & 44 & 73,3 & 18 & 30,0 & \multirow{2}{*}{43,3} \\
\hline Good & 16 & 26,7 & 42 & 70,0 & \\
\hline
\end{tabular}

Based on Tabel 2, the skill of handwashing with soap before intervention (8,3\%). After the intervention, there was an increasing skill of handwashing with soap in which all 44 respondents $(73,3 \%)$. An increase of $65 \%$ in skill was observed after the use of video animation..

Table 2 Description of Children Practice in Hand Washing with Soap

\begin{tabular}{cccccc}
\hline Practice & \multicolumn{2}{c}{ Before Intervention } & \multicolumn{2}{c}{ After Intervention } & Enhancement \\
\cline { 2 - 6 } & $\mathrm{n}$ & $(\%)$ & $\mathrm{n}$ & $(\%)$ & $(\%)$ \\
\hline Bad & 55 & 91,7 & 16 & 26,7 & 65,0 \\
Good & 5 & 8,3 & 44 & 73,3 & \\
\hline
\end{tabular}


From the result of normality test, it was found the value of Kolgomorov-Smirnov for knowledge pretest (1.48) and knowledge posttest (0.34), skills pretest (0.92) and skills posttest (0.91). Since the value of Sig. for pretest and posttest is higher than 0.05 , it is concluded that the data are normally distributed. Therefore, the paired sample $t$ test can be done.

Table 3 Effect of Video Animation on Children Knowledge

\begin{tabular}{cccccc}
\hline Knowledge & Mean & SD & SE & $\begin{array}{c}\text { Paired } \\
\text { Difference }\end{array}$ & P value \\
\hline Pretest & 3.13 & 0.45 & 0.058 & 5.407 & 0.000 \\
Postest & 4.93 & 0.46 & 0.060 & & \\
\hline
\end{tabular}

Base on Tabel 3, the average value of knowledge before intervention carried out was 3.13, while after the intervention, the mean value of knowledge was 4.93 with a difference of 5.407. The results of the paired t-test statistical test showed that $p$ value of $(0.000)<0.05$, this proved that there was a significant difference between knowledge about handwashing with soap video animation before and after intervention.

Table 4 Effect of Video Animation on Children Practice

\begin{tabular}{cccccc}
\hline Practice & Mean & SD & SE & $\begin{array}{c}\text { Paired } \\
\text { Difference }\end{array}$ & P value \\
\hline Pretest & 0.08 & 0.279 & 0.036 & 10.468 & 0.000 \\
Postest & 0.73 & 0.446 & 0.058 & & \\
\hline
\end{tabular}

Base on Tabel 4, the average value of skill before intervention carried out was 0.08 , while after the intervention, the mean value of skill was 0.73 with a difference of 10.468 . The results of the paired t-test statistical test showed that $\mathrm{p}$ value of $(0.000)<0.05$, this proved that there was a significant difference between skill about handwashing with soap video animation before and after intervention.

\section{Discussion}

Based on result of data analysis above, the researcher explain that the student of the $6^{\text {th }}$ grade students of SD Negeri Cigabus faced some difficulties in handwashing skills and based on questionnaire that had given the difficulties faced students were the students did not understand the handwashing with soap.. 
The improvement of handwashing whith soap video animation was also shown by the result of pre-test and post-test. The result showed that the mean score knowledge of post-test was higher rather than the mean score of pre-test $(4.93>3.13)$ and also mean score skill of post-test was higher rather than the mean score of pre-test $(0.73>0.08)$. Based on the result proved that, video animation was effective to improve students handwashing skill rather than conventional learning.

This research uses video animation which can make students better to understand about handwashing skill. During the learning process where students get a stimulus to be able to focus more and make it easier to understand the material provided, with the help of media that makes students easy to understand about handwashing skill. The demonstration of hand hygiene technique regarding hand hygiene was effective in improving the practices of hand hygiene of

elementary school going children and thus administration of steps of hand hygiene technique was easy to understand. (Mane \& Tata., 2017). The animation media, as the alternative media for the students, provides a better experience for students. (Gellerstedt et al., 2018). Especially if enriched with multimedia (picture, animation, music, sound), a video can motivate, attract and gather the students' attention. (Yakovleva \& Goltsova, 2016).

\section{F. CONCLUSIONS}

Based on the results of research conducted that the handwashing health education using video animation was effective to increase the knowledge and skills of school children regarding the proper of handwashing in elementary school. It was proven by the result of this study. Based on the result show that increase of $43,3 \%$ in knowledge was observed after the use of video animation and increase of $65 \%$ in skill was observed after the use of video animation. It indicated that after implementing treatment through video animation the students were able to achieve better knowledge and skills handwashing with soap. The results of the paired t-test statistical test showed that $\mathrm{p}$ value of $(0.000)<0.05$, this proved that there was a significant difference between knowledge and skill about handwashing with soap video animation before and after intervention. 


\section{REFERENCES}

Aditya, K.A.D, Putu Kerti Nitiasih, P.K, Budiarta,L,G.R (2020). The Effect Of Gamification Based On Balinese Local Story Toward Students' Listening Comprehension. Acitya: Journal of Teaching \& Education, Vol. 2 No. 22022.

Ary, D., Jacobs, L. C., \& Sorensen, C. (2010). Introduction to research in education (8th ed.). New York: Wordsworth Thomson Learning.

Brame, C.J. (2016). Effective Educational Videos: Principles and Guidelines for Maximizing Student Learning from Video Content. CBE-Life Sciences Education. 15:es6, 1-6, Winter 2016.

Buda, A.S, Mekengo, D.E, Terefe Markos Lodebo, T.M, Abinet Arega Sadore. A.A, Mekonnen, B. (2018). Knowledge, attitude and practice on hand washing and associated factors among public primary schools children in Hosanna town, Southern Ethiopia. J. Public Health Epidemiol.Vol. 10(6), pp. 205-214, June 2018.

Gellerstedt, M., Babaheidari, S.M., Svensson, L. (2018). A First Step Towards A Model For Teachers' Adoption of ICT Pedagogy In Schools. Heliyon, 4(9), 1-17. Retrieved on January 6, 2019 from https://www.sciencedirect.com/science/article/pii/S218317304.

Garg, A., Taneja, D.K, Badhan, S.K, Ingle, G.K. (2013). Impact of a School-Based Hand Washing Promotion Program on Knowledge and Hand Washing Behavior of Girl Students in a Middle School of Delhi. Indian Journal of Public Health, Volume 57, Issue 2, AprilJune, 2013.

Hapsari, A.S., Hanafi, M., Gunarhadi, Roemintoyo. (2019). Motion Graphic Animation Videos to Improve the Learning Outcomes of Elementary School Students European Journal of Educational Research Volume 8, Issue 4, 1245-1255. Retrieved on January 24, 2020 from https://www.eu-jer.com/motion-graphic-animation-videos-to-improve-the-learningoutcomes-of-elementary-school-students. 
Kementerian Kesehatan Republik Indonesia (2019). Video Animasi, Ayo Cuci Tangan Pakai Sabun. Kementerian Kesehatan Republik Indonesia. Direktorat Promosi Kesehatan dan Pemberdayaan Masyarakat. Retrieved on January 2, 2019 from https://promkes.kemkes.go.id/video-animasi---ayo-cuci-tangan-pakai-sabun.

Kementerian Kesehatan Republik Indonesia (2020). Panduan Cuci Tangan Pakai Sabun. Direktorat Kesehatan Lingkungan. Retrieved on January 2, 2020 from https://kesmas.kemkes.go.id/assets/upload/dir_519d41d8cd98fo0/files/Panduan_CTPS2020_ 1636.pdf.

Kementerian Kesehatan Republik Indonesia (2018). Laporan Nasional Riset Kesehatan Dasar (RISKESDAS) 2018. Kementerian Kesehatan Republik Indonesia. Badan Penelitian dan Pengembangan Kesehatan.

Marantika, A., Dwihestie, L.K. (2020). The Effect Of Health Counseling On Handwashing Technique In Primary Schools. Indonesian Journal of Global Health Research Volume 2 Number 3, August 2020, pp. 217-224.

Mane, M.A, Tata, S.H. (2017). A Study to Assess the Effectiveness of Hand Hygiene Technique among School Children in Maharashtra, India. Asian Journal of Pharmaceutical Research and Health Care, Vol 9 (4), 174-179, 2017.

Naylor, S.,Keogh, B. (2013). Concept cartoons: What have we learnt? Journal of Turkish Science Education, 10(1), 3-11.

Pratiwi, Y.S., Nataprawira, H.M., Noegroho, B.S. (2019). Effects of Android-Based Sayang ke Buah Hati (SEHATI) Application towards Mothers' Knowledge and Children's Skill on Hand Washing with Soap. Global Medical and Health Communication, Volume 7 Number 2, August 2019. Retrieved on Ocotber 27, 2020 from https://ejournal.unisba.ac.id/index.php/gmhc/article/view/2756. 
Rajagukguk, T.A, Herman, Partohap S. R, Sihombing (2020). The Effect Of Using Collaborative Writing Method On Students' Writing Recount Text At Grade Ten Of SMK YP 1 HKBP Pematangsiantar. Acitya: Journal of Teaching \& Education, Vol. 2 No. 22020.

Sastroasmoro, S., \& Ismael, S. (2011). Dasar-dasar metodologi penelitian klinis. Jakarta: Sagung Seto.

Sugiyono. (2010). Statistika untuk Penelitian. Bandung: Alfabeta

Umwangange, M.L. (2016). The Effectiveness of Handwashing Health Education Session on Raising School Children's Knowledge and Skills of Proper Handwashing Technique. a Pre test- Post Test Design.Texila International Journal of Public Health Volume 4, Issue 4, Dec 2016.

Wiana, W., Barliana M. S., \& Riyanto, A. A. (2018). The effectiveness of using interactive multimedia based on motion graphic in concept mastering enhancement and fashion designing skill in digital format. International Journal of Emerging Technologies in Learning, 13(2), 4-20.

Wibowo A (2014). Metodologi Penelitian Praktis Bidang Kesehatan. Jakarta: RajaGrafindo Persada.

Yakovleva, Y.V., Goltsova, N.V. (2016). Information And Communication Technologies As A Means Of Developing Pupils' Learning Motivation In Elementary School. Procedia-Social and Behavioral Science, 233, 428-432. Retrieved on January 13, 2019 https://www.sciencedirect.com/science/article/pii/S1877042816314124. 